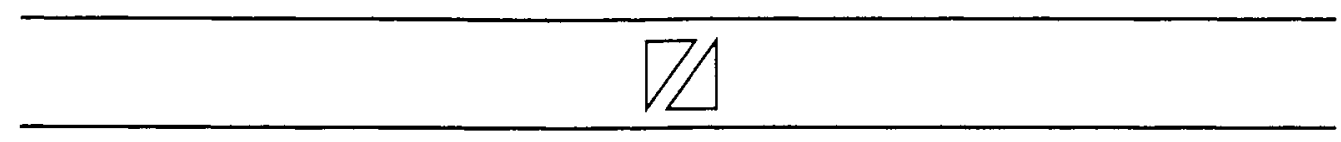

\title{
FANTASIES OF DOMESTI(CITY)
}

\author{
GÜlsüM BAYDAR NALBANTOĞLU
}

\begin{abstract}
If a city, according to the opinion of philosophers, be no more than a great house and, on the other hand a house be a little city; why may it not be said, that the members of that house are so many little houses. - Leone Batisti Alberti, 1755
\end{abstract}

A detail in a city means a house multiplied a hundred thousand times; therefore it is the city.

- Le Corbusier, 1924

[The] protocol of physical access gave all its meaning to the space of a dwelling and of a City; both were linked to the primacy of the sedentary over the nomadic ways of our origins. And all of this is being swept away by advanced technologies, especially those of domestic teledistribution. - Paul Virilio, 1984

The conjunction of the terms 'city' and 'house' provides an extraordinary link between these three quotations from paradigmatic texts of radically different historical locations. The house and the city arguably occupy two extreme ends of the architectural scale and the modernist imagination has placed them at the opposite ends of the private/public divide. Home is constructed as the mythologised space of privacy that is connected with an originary identity. It is the unpolluted place of the nurturing mother. The city is the father's place. It is the public scene of the streets, social life and politics. Here the feminine figure bears the mark of seduction. Sexualised metaphors of the city and the home persistently emphasise the eroticised thrill of the metropolis and the familial haven of home. ${ }^{1}$ Keeping these highly charged oppositions in mind, it is striking to see the repetitive appearance of the figure of the house in the texts of leading urban theorists who are rooted in the discipline of architecture. Questions proliferate: If repetition is a mark of difference rather than progress, what is the surplus that this repetitive conjunction produces? What role does 
the figure of the house play in urban discourse? What to make of the city/ house conjunction at a time when the discipline is alarmed by the loss of both?

There are further commonalities between the discursive contexts of the three quotations that I will pursue in my paper. All bear the burden of redefining the city on the basis of a perceived crisis rooted in technology military, transportation and communication technologies respectively. All three cases describe the crisis in terms of fragmentation, disappearance and loss. What we have then, are three urban narratives that deploy similar terms in understanding and explaining historical breaks in the architectural identification of the city. By using the house as a metaphor, the first two explicitly rely on it as a stable and known identity to state what the city is. The third one announces the loss of the meaning of both the house and the city. What is at stake here is not.only the identification of the city but the house as well. But which city and which house?

It should be clear by now that my chronological alignment of the three quotations is not of historical interest. Rather than the history of the city, I am interested in its re-production in architectural discourse. Turning back to the three quotations, rather than taking the city and the house simply as pre-given objects of architecture, I want to investigate how these are produced and linked in specific ways by architecture's disciplinary strategies. What does the city mean for architecture and how does the house function in the production of this meaning?

\section{Scene $I . .$. a city ... be no more than a great house}

A number of contemporary theorists have argued that the concept of the city as a built object and as a unified entity did not exist before the fifteenth century (Lefebre 1991; Choay 1997; see also Burgin 1996). Indeed, the city is a significant preoccupation of the architectural treatises of the Renaissance. Earlier texts present it as an aggregation of public and private buildings but not as a spatial unity. Hence, the constitutive moment of Western architectural discourse exists prior to its incorporation of the city. Renaissance theorists embrace the Vitruvian precept that 'the well-shaped man' provides the measure and proportion of all architectural elements in a building (1960:72). The city, when it becomes an architectural subject, is conveniently absorbed in this framework. In that sense, the law of perfection precedes the perfect city. Alberti's statement that the city is no more than a great house and the house is a little city and that every edifice 'should appear to be an entire and perfect body and not disjointed and unfinished members' is exemplary in this respect (1996:13). At this level, what conjoins the body, the house and the city is their intact boundaries that ensure wholeness.

As such the ideal city of the Renaissance emerges in a striking historical narrative. In 1430 Poggio Bracciolini who drew up the first systematic 
inventory of the fragmentary remains of ancient Rome, declared that 'once the most beautiful and magnificent of cities ... today, stripped of all her adornments, lies decaying like a gigantic corpse, every part having been mutilated' (quoted in Choay 1997:53). Indeed, the Roman ruins as much as Vitruvius' treatise were instrumental in the formulation of the Renaissance city. What makes Bracciolini's statement remarkable is its reference to the disintegration of the city in relation to woman's body. ${ }^{2}$ The imagery is that of rape. The mutilated body of the fallen woman is to be re-membered and protected from further assault. How?

It is well known that the early modern architectural texts' primary preoccupation is the city walls. The walls both define the city as a contained entity and ensure its survival against war technologies. The city's architectural materialisation is based on the threat of its dissolution. In other words, the city is stigmatised by its dissolution at the very moment of its emergence as a finite unity. The boundary gains priority as the guarantee of an intact and inviolable form.

The metaphors of the female body and the house become more complicated at this juncture, and I want to discuss this in the light of a powerful illustration in Francesco di Giorgio Martini's late fifteenth-century treatise. Di Gicrgio says that 'one should shape the city, fortress, and castle in the form of a human body, that the head and the attached members have a proportioned correspondence and that the head be the rocca, the arms its recessed walls, which, circling around, link the rest of the whole body, the vast city' (quoted in Agrest 1991:183). In the illustration that accompanies the text, the contours of the body are literally the boundaries of the city. They stand in for the walls. The dissolution of the city is simultaneous with the body's dissolution - and the body here is explicitly marked as male. ${ }^{3}$ The use of the body metaphor indicates the desire for controllable boundaries. Concepts are not simply illustrated but produced by metaphors. ${ }^{4}$ Re-membering the mutilated woman's body turns out to be an impossibility, perhaps because she was never membered at first place. The figures of the body, the mutilated woman and the intact man are produced by, and in turn produce, specific ways of conceiving, perceiving and constructing urban space.

How, then, does the house metaphor function in this scenario? In an inspiring study on Alberti's texts, architectural theorist Mark Wigley demonstrates how sexuality functions in the Renaissance discourse on the house (1992:327-89). In doing so, he complicates the commonplace juxtapositions of the city and the house with male and female identifications respectively. In a remarkable instance Alberti says:

Women ... are almost all timid by nature, soft, slow, and therefore more useful when they sit still and watch over things. It is as though nature thus provided for our well-being, arranging for men to bring 
things home and for women to guard them. ... The man should guard the woman, the house, and his family and country, but not by sitting still. (Alberti 1969:III, 207, quoted in Wigley 1992:334)

As Wigley argues, the woman's duty is to guard the house according to the law that precedes both her and the house. This is the law of the father, the law of marriage as the taming of desire, and the law of order and surveillance. Hence the Albertian notion of domesticity is based on masculine control over sexuality and desire. As Wigley explains, if the woman goes outside she is more dangerously feminine rather than more masculine' (1992:335). The house, on the other hand, is a site of order and purification. The primal scene of the mutilated woman as a metaphor of the destructed city, and the construction of the city in the image of the male body make more sense now. The woman outside is a fallen woman. She needs to be located in the house which is ordered in the image of man. The city as a large house contains and controls the feminine element but is identified as male.

The city as a large house then marks an architectural fantasy of total control. In that sense the house, where domestication and mastery are always already established, provides the fantasmic support for the city as an ideal site. I use the notion of fantasy here in the psychoanalytical sense and not in its everyday use as the opposite of reality. Placing fantasy on the side of - rather than in opposition to - reality, Lacanian psychoanalysis argues that fantasy is the support that gives consistency to what is called 'reality'. Architecture needs a phantasmic frame to identify the city as a site of order and control. The figure of the house materialises that frame. Fantasy 'functions to hide the palpable void of nothingness and meaninglessness - death - at the centre of apparent meaning or appearance' (Ragland-Sullivan 1992:59). The fantasy of the ideal city suppresses the wild forces of unpredictability and difference, and structures the desire to reconstruct and regulate existing cities. The dead woman's body then marks the symbolisation of the loss that an idealised urban identification is based on. After her death, the city can be symbolised as an architectural reality with the support of the house and the body.

\section{Scene II. ... a house multiplied a hundred times ...}

A primal scene sets the stage for Le Corbusier's 1924 publication, The City of Tomorrow. The book was written during the emptiness of a Paris summer when the city was quiet and underpopulated. 'Then came the autumn season,' the architect says and,

Day by day the fury of traffic grew. To leave your house meant that once you had crossed your threshold you were a possible sacrifice to death in the shape of innumerable motors. I think back twenty 
years, when I was a student; the road belonged to us then; we sang in it and argued in it, while the horse-bus swept calmly along.

With a striking change of tone he continues:

On that 1st day of October, on the Champs Elysees, I was assisting at the titanic reawakening of a comparatively new phenomenon, which three months of summer had calmed down a little - traffic. Motors in all directions, going at all speeds. I was overwhelmed, an enthusiastic rapture filled me. Not the rapture of the shining coachwork under the gleaming lights, but the rapture of power. The simple and ingenuous pleasure of being in the centre of so much power, so much speed. We are part of it. We are part of that race whose dawn is just awakening. ... Its power is like a torrent swollen by storms; a destructive fury. The city is crumbling, it cannot last much longer. (1987:xxiii)

The city is on the verge of disappearance. The safe house now stands in opposition to the deadly streets of human sacrifice. It is interesting to note that in Le Corbusier's discourse an abstract notion of the city stands separate from speed and traffic that poses threat. 'The city is crumbling' but speed and traffic stand as independent sources of power. This is sheer power without an object and without location. While the city is crumbling, as Le Corbusier states later in the book, 'the idea of the 'old home' disappears' as well (ibid.:231). Since the 'house' itself is threatened, there remains no room for the Albertian notion of the city as a large house.

What interests me here is the contradictory tones that mark Le Corbusier's discourse. The first part of his account resonates with nostalgia; a yearning for his familiar childhood city. This is in harmony with the Albertian desire for the city as a large house. The second part, on the other hand, bears the mark of seduction. The architect is apparently seduced by the uncontrollable power that overtook the familiar city. In psychoanalytical terms, his experience of the city is 'beyond the pleasure principle'. This is a paradoxical pleasure rooted in displeasure. The architect and the city, the subject and the object are momentarily conjoined by the flow of speed and power. The second part of Le Corbusier's account marks the brief moment of jouissance in the text which erupts from an inadvertent crack in the urban identification based on the metaphor of the house. Ironically, the cost of Le Corbusier's bliss is the very city itself. The sudden turn of the text is a striking revelation that death and jouissance are embedded in the same mise-en-scène. Le Corbusier's encounter with the city is uncannily similar to the ancient myth of Odysseus' encounter with the sirens, creatures, half-woman and half-bird, who live on an island and have the power of enticing men with their singing. Those who succumb 
die immediately. Odysseus, whose ship passes their island, deals with the situation by filling the ears of his men with wax and having himself fastened to the mast. The sirens then drown themselves from vexation at his escape. The question of what the sirens sang or whether they sang at all are left open. In a brilliant analysis of the myth, Renata Salecl argues that the sirens' song stands as an empty, unutterable point in the Odyssey which conjoins seduction and death (1998:175-98). It stands for the failure of symbolisation just as the force of sheer power, emptied of any material content, stands for the failure of the city in Le Corbusier's account. How, then, does the architect design his Contemporary City for Three Million Inhabitants which is the focus of his book? How does he reconcile his nostalgia for familiarity and his bliss in the city's death?

At this point, Salecl's inspiring comparison between the sirens and the muses enables further theorisation. The muses, who are the singers that preside over thought and creativity, sing songs of past glories to make men forget their troubles. 'Inspired by the memory that the muses provide, their listeners are able to create works of art, while those who hear the knowledge offered by the sirens' song immediately die' (ibid.:179). Despite its inspiration by the sirens' song then, is the City for Three Million a response to the call of the muses? Is it inspired by a yearning for 'the city as a large house' rather than the unsymbolisable power that marks the former's death? For Le Corbusier, the city is not a large house, however. He says that it is 'a house multiplied a hundred thousand times' (1987:71). What to make of this repetition?

The City for Three Million is a complicated project that needs to be interpreted at a number of levels. At one level, as the architectural discipline has it, it is a magnificent manifestation of an ideal modernist city at the age of transportation and speed. Its orderly layout, clear zoning and traffic management marks the attempt to recover the loss of familiarity and belonging. As such, it is an urban fantasy that avoids the trauma of the city's disappearance. At another level, however, I want to argue that the project reveals its own limits in interesting ways. The house enters as a crucial figure in this reading. Let me turn to the notion of the city as a house multiplied a hundred thousand times. The City of Tomorrow overflows with statements of determined insistence on mass produced houses and the notion of the house-machine. How can we explain this drive to repeat? I am tempted to interpret it in terms of the proposition that 'the drive is in the final instance always the death drive'. To further this analysis let me turn to the meaning of the house for Le Corbusier.

Based on Le Corbusier's drawings and photographs of his houses, architectural theorist Beatriz Colomina argues that for him the house is not defined on the basis of domestic interiority (1992:73-130). On the contrary, it is a device to frame the exterior. To inhabit means to see. The look is not genderneutral however. The architect consistently depicts women facing the interiors and men looking out. Interestingly however, all traces of traffic, speed and 
urban life are eliminated from the views that Le Corbusier's houses are meant to frame. What we get are picturesque landscapes of a domesticated nature. The city is a house multiplied a hundred thousand times but, in making the city, a hundred thousand houses annihilate it. The narrative of loss doubles in Le Corbusier's account. The loss of the city of his childhood is accompanied by another and more traumatic loss - the loss of the city itself. That is precisely where the notion of the death drive becomes important: it marks the eradication of the symbolic texture which constitutes reality (Zizek 1989:132). ${ }^{5}$ For the source of jouissance lies at the unsymbolisable kernel at the core of the symbolic order. In my reading, what makes The City of Tomorrow an important project lies less in its being a modernist manifestation of what an ideal city includes than in its inadvertent disclosure of the lack that emerges at its founding moment.

The figure of the house then plays a double role in the City for Three Million. First, it plays the role of fantasmic support that makes the city possible. By structuring the very architecture of the city, it covers over the image of the disappearing city that Le Corbusier experienced in his moment of jouissance. At the same time, however, its incessant repetition marks the obliteration of the symbolic weave that constitutes the city as an identity category.

Scene III. ... all of this is being swept away ...

Both the Albertian and the Corbusean responses to the loss of the city take the form of urban ideals. As such they posit 'ideal' cities as objects of desire to enable 'real' urban intervention. The figure of the house plays a crucial role here in symbolising the loss and hence providing the fantasmic support for the recovery of urban identification. If the Albertian and Corbusean idealisations mark the ends of two narratives based on loss, the contemporary discourse on cities of the information age mark the beginning of yet another one. Paul Virilio is one of the most vocal critics in that respect. In an exemplary paragraph in 'The Overexposed City', he states:

Today, the abolition of distances in time by various means of communications and telecommunications results in a confusion in which the image of the City suffers the direct and indirect effects of iconological torsion and distortion, in which the most elementary reference points disappear one by one. With the decay of urban centrality and axiality, the symbolic and historic reference points go first. Then, when the industrial apparatus and the monuments lose their meanings, the architectonic references vanish. Most decisively, the demise of the ancient categorisation and partition of the physical dimension leads to the loss of the geometric reference points. (1991:30) 
Abolition, confusion, torsion, distortion, decay, loss, disappearance, demise are all negative terms that point to dissolution and death. Interestingly, at this junction the figures of the body, the house and the city are linked one more time. Stating himself to be 'a materialist of the body', Virilio is extremely critical of its 'de-realisation' by the invasion of transplants, biogenetic devices and developments in nanotechnology. Similar to the disappearance of the 'real body', the dissolution of the city and the dwelling too are linked to technological developments. The issue here is the breakdown of physical boundaries. As Virilio explains, the city gate is replaced by the security gateway at the airport and the house-window with the screen interface. The protocol of physical access, as opposed to advanced technologies and teledistribution systems, he contends, 'gave all its meaning to the space of a dwelling and of a City; both were linked to the primacy of the sedentary over the nomadic ways of our origins' (ibid.:99).

Virilio's arguments are multilayered and complex but the above quotation bears an unmistakable mark of emasculation. Indeed, sexuality is explicitly woven into his statements on the progressive loss of habitable space. As Verena Andermatt Conley argues, 'repeatedly, Virilio claims that woman is man's first vehicle in a series of relays that leads from the prehistoric pugilat [fight] to present-day teletopia and that goes along with the progressive loss of "Mother Earth"' (1999:202). ${ }^{6}$ With reference to the story of Genesis, he ascertains that man's seduction by woman led him astray on his search for the perfect technological object. This parallels the eroticised feminisation of loss in Alberti's and Le Corbusier's discourses. In the former instance, the city is literally lost as the result of warfare and associated with the mutilated woman's body. In the latter, physical disturbances such as noise and traffic bear the burden of loss and the sign of seduction. In both cases the house provides the fantasmic frame that holds the image of the city. It is that frame that provides meaning to the material reality of the city. It seems to me that today that very frame is experienced as loss. Virilio explicitly says that it is the 'image' of the city and its 'meaning' that vanish. Since the source of meaning for both the city and the house has vanished, the house can no longer function as the metaphor for the-city-to-be. Indeed, today the house turns out to be the source of urban dematerialisation. William J. Mitchell's City of Bits, has a lengthy section entitled, 'Electronic Agoras' which begins with explaining how his home computer collapses the spaces of the office, the marketplace, the neighbourhood café, the Main Street and all aspects of formerly 'urban' life (1996: 7-24). Has the Albertian ideal come full circle then? Is the home literally a small city now? What is the role of architecture in this scenario?

I now want to turn to the architecture of the house and enter Bill Gates's 'home of the future' in Seattle. Gates describes his house in his renowned book, The Road Ahead, in the section appropriately entitled, 'Plugged in at 
Home'. As he explains, the house is made of wood, glass, concrete and stone. The wood is recycled Douglas fir from an eighty-year-old lumber mill (1995:214). It stamps the house with the mark of stability, authenticity and history - the unmistakable signs of domesticity. However, the house is also made of other materials, 'of silicon and software' as Gates states. Indeed, there is abundant use of digital and electronic technology in this house. The owner explains:

First thing as you come in you'll be presented with an electronic pin to clip to your clothes. This pin will connect you to the electronic services of the house ... will tell the house who and where you are, and the house will use this information to try to meet and even anticipate your needs - all as unobtrusively as possible. (lbid.:217-18)

Thanks to the pin, the occupants will be accompanied by a moving light zone, personalised music, movies and news as they move around the house. In the case of a phone call, only the handset nearest the addressee will ring. All evidence of silicon microprocessors, memory chips and software equipment, however, is concealed behind traditional building materials. 'My hope is that the view and the Douglas fir, rather than the electronic pin, will be what interest you most,' says Gates in a most revealing statement. I think that this is a striking response to the prevalent conviction about the diminishing role of architecture in the age of electronic technologies.?

I would argue that in the Gates house, architecture-as-we-know-it plays a fundamental historical role in demonstrating the limit of the Albertian fantasy that the city is no more than a great house and the house is a little city and that every edifice is a body. The Gates house is indeed a little city at a number of levels. This is due less to its public meeting spaces such as a theatre and a reception hall than to the electronic communication devices that enable the entire house to absorb such urban functions as museums, concert halls and offices. All these facilities are made available by means of the electronic pin that is attached to the body. The city invades the house. The house implodes and invades the body. The Albertian ideal comes full circle. The city and the body merge via the house. The architecture of the house plays a crucial role here in covering up the dramatic limit of the Albertian fantasy. This is the limit whereby the city, the house and the body are totally synchronised. In this scenario, the house can no longer function as the fantasmic support for the identification of the city. This is not only because the two identifications merge, but also because what remains of the house and the city is only architecture (the perceptual shell that conceals the reality of electronic devices which regulate any notion of interiority) which now functions as a mask to cover over the void left by the death of domestic interiority - domesti-city. 


\section{RE-MEMBERING THE CITY}

I have argued that the metaphor of the house functions as a fantasmic support for the architectural identification of the ideal city. It guards against the city's disintegration, and its ultimate death. Indeed, notions of loss and death appear at a number of levels in my argument. First and most fundamental of course, is that the very question of the city emerges simultaneously with its experience as loss. The ideal city marks the symbolisation of 'the thing' that is lost. Second, death is woven into my argument in relation to feminine identification. In the Albertian instance, the metaphor of the dead woman not only symbolises the disintegrated city but also the impossibility of its recovery. Also, in both the Albertian and Corbusian instances, the definition of the house, the fantasmic support of the city is based on the eviction and the death of feminine identification. Third, in the latter instance, the notion of the death drive helped me to explain the impossibility of fulfilling the premises of the ideal city.

In all these instances, the urban imaginary which operates on the principle of recovery, fulfils the social symbolic requirements of mastery and control. Recovery in that sense turns out to be re-covery-covering over the perceived loss. I would like to argue that once the notion of loss is critically examined, there may be other imaginary identifications for the home and the city. ${ }^{8}$ Perhaps then, Virilio's statement on the loss of meaning will hold the very promise and possibility of locating meaning away from the interiority that the home metaphor builds. Since meaning, by definition, depends on the symbolisation of the founding loss, the question cannot be to discard this powerful notion. If we accept the psychoanalytical proposition that the lost object was not there at first place, but emerges as being lost, we will accept the inherent impossibility of its reconstruction. There must be other ways of producing meaning than the (failed) reconstruction of its founding loss.

How to relocate the desire for meaning? How to productively undo the messy entanglement of the notions of loss, recovery and meaning? I find Kaja Silverman's insistence on the importance of embracing the futural manifestation of the past extremely inspiring here (1999:90-91; see also Silverman 1996:180-83). Following psychoanalytical theory, her argument is that since the backward path to satisfaction is blocked, we have no choice but to move forward. On this new path, the desired object can only be recovered in the form of a substitute. What is too often forgotten is that every re-membrance involves a displacement and hence alterity. A productive involvement with the past is possible by capitalising neither upon the return, nor upon the particularity of the new term, but on the possibilities opened up by displacement. Silverman emphasises that our capacity to care is rooted in the past, as the very perception of loss provides us with the capacity to cherish and care. What is important here is that this capacity is always subject to retroactive rearticulations. 
In terms of my own argument then, our urban projections will inevitably be rooted in experiences of loss. The point is that there are other ways of handling these experiences than either mourning over the loss or euphorically celebrating the new terms. Productive symbolisation of the latter is enabled by the invocation of care that is embedded in a retroactive orientation. Indeed, recent critical work on specific urban sites suggests that the immediacy of the present offers abundant urban instances that are yet to be symbolised (see, for example, Lozanovska 1997; Sherif 1999; Nalbantoğlu 1999). Each time we allow these instances to appear in architectural and urban terms, we have the opportunity to turn away from the urban enclosure based on the violence inherent in the metaphor of home. Since our perceptual and enunciative positions are always historically, geographically and socially located, these instances can proliferate ad infinitum. Today, as war and disasters, as much as electronic communication devices literally obliterate urban boundaries, and reconstruction projects proliferate, our experiences and perceptions of loss can lead to different bodily, domestic and urban imaginaries that are not rooted in domesti-city.

\section{NOTES}

1. Sue Best cites a considerable number of examples, from architect Rem Koolhaas's description of New York to philosopher Francois Lyotard's account of Los Angeles to support this proposition. One of the most prominent thinkers who uses maternal references in relation to the concept of home is, of course, Gaston Bachelard (see Best 1995:181-83).

2. Mario Gandelsonas states that 'the city has been the object of architectural desire from the moment architectural discourse was established with Albert's theory: An articulation of two illegible texts, one written (Vitruvius's Ten Books on Architecture) and one built (the Roman ruins)' (1998:130). Bracciolini's statement is not the only historical instance where an association is made between woman's body and the city. In an inspiring commentary on the architectural/archaeological discourse that surrounds the impression of a woman's breast on a piece of earth in Pompeii, Mirjana Lozanovska observes that 'there are spontaneous, almost automatic gestural, spasmatic links between woman, death and buried city: eroticism as subtext can only be symbolized within an economy of death' (1999:236).

3. For an inspiring account of how sexuality functions in Renaissance treatises see Agrest 1991:173-95. In fact, the invocation of space in relation to the body as a bounded entity is an historically recurring theme. Citing Mary Douglas, Sue Best argues that the body provides the model for any bounded system (1995:183).

4. From a poststructuralist perspective a number of contemporary theorists have emphasised the problematic separation of image and meaning in 
the use of metaphor (see Best 1995:185-88; Wigley 1993, esp. 'The Domestication of the House', pp.97-122).

5. Zizek explains that in the late work of Lacan the symbolic order is identified with the pleasure principle beyond which lies a traumatic, unsymbolisable core. At that level, the death drive is the opposite of the symbolic order, 'the radical annihilation of the symbolic texture through which the so-called reality is constituted. The very existence of the symbolic order implies a possibility of its radical effacement, of "symbolic death" - not the death of the so-called "real object" in its symbol, but the obliteration of the signifying network itself' (1989:132).

6. Conley's ultimate project is to point to rare turns in Virilio's texts where the space opened to movement in connection with eros might enable transformations outside the totalitarian closure that Virilio anticipates. Other articles in the same issue of Theory, Culture and Society in which Conley's article appears to go further to illuminate the multiplicity of interpretations evoked by Virilio's position.

7. In a recent and informative article on the Gates house, for example, Adi Shamir Zion contends that while historically architecture had an implicit connection to building techniques, information technology seems not to require architectural response and participation. Her project is to reform architecture in the light of a 'new modern', harking back to the transformations in spatial perception in the early twentieth century. In a sense, this is yet another narrative of a golden past, unwanted present and future recovery (1998:78).

8. I use the term imaginary identification in the psychoanalytic sense here, indicating identification with the image in which we appear likeable to ourselves, i.e., the ideal ego (see Zizek 1989:105).

\section{REFERENCES}

Agrest, Diana. 1991. Architecture from Without. Cambridge Mass.: MIT Press.

Alberti, Leon Battista. 1969. Della Famiglia, trans. Renee Neu Watkins as The Family in Renaissance Florence. Columbia: University of South Carolina Press.

1986. The Ten Books of Architecture, repr. of 1755 Leoni Edition. New York: Dover Publications.

Best, Sue. 1995. Sexualizing Space. In Elizabeth Grosz and Elspeth Probyn (eds), Sexy Bodies. New York: Routledge.

Burgin, Victor. 1996. The City in Pieces.in In/Different Spaces. Berkeley: University of California Press.

Choay, Françoise. 1997. The Rule and the Model: On the Theory of Architecture and Urbanism, ed. Denise Bratton. Cambridge Mass.: MIT Press. 
Colomina, Beatriz. 1992. The Split Wall: Domestic Voyeurism. Sexuality and Space. New York: Princeton Architectural Press.

Conley, Verena Andermatt. 1999. Virilio and Feminism. Theory, Culture and Society 16(5-6). Special issue on Paul Virilio, ed. John Armitage.

Gandelsonas, Mario. 1998. The City as the Object of Architecture. Assemblage 37, Dec.

Gates, Bill. 1995. The Road Ahead. New York: Viking.

Le Corbusier. 1987 [1924]. The City of Tomorrow. London: The Architectural Press.

Lefebvre, Henri. The Production of Space, trans. Donald Nicholson-Smith. Oxford: Blackwell.

Lozanovska, Mirjana. 1997. Abjection and Architecture: The Migrant House in Multicultural Australia. In Gülsüm Baydar Nalbantoğlu and Wong Chong Thai (eds), Postcolonial Space(s). New York: Princeton Architectural Press.

1999. Abreast of the Other: Circular Methodologies between Archaeology, Architecture and War. In Sites of Recovery: Architecture's [Inter]disciplinary Role, Conference Proceedings, Beirut, Oct. 25-28.

Mitchell, William. 1996. City of Bits. Cambridge, Mass.: MIT Press.

Nalbantoğlu, Gülsüm Baydar. 1999. Migration, Memory, Architecture. Paper presented at the conference, Frontiers of Memory, University of East London, Sept. 17-19.

Ragland-Sullivan, Ellie. 1992. Death Drive. In Elizabeth Wright (ed.), Feminism and Psychoanalysis: A Critical Dictionary. Oxford: Blackwell

Salecl, Renata. 1998. The Silence of the Feminine Jouissance. In Slavoj Zizek (ed.), Cogito and the Unconscious. London: Duke University Press.

Sherif, Lobna. 1999. The Multi-faceted Realities of Recovery in Cairo. In Sites of Recovery: Architecture's [Inter]disciplinary Role, Conference Proceedings, Beirut, Oct. 25-28.

Silverman, Kaja. 1996. The Threshold of the Visible World. New York: Routledge. 1999. Prolegomena to 'World Spectators'. In Ursula Frohne (ed.), Video Cult/ures. Karlsruhe: Museum fur Neue Kunst.

Virilio, Paul. 1991. The Overexposed City. In The Lost Dimension. New York: Semiotext(e).

Vitruvius. 1960. The Ten Books on Architecture, transl. Morris Hicky Morgan. New York: Dover Publications.

Wigley, Mark. Untitled: The Housing of Gender. Sexuality and Space. New York: Princeton Architectural Press.

The Architecture of Deconstruction. Cambridge, Mass.: MIT Press.

Zion, Adi Shamir. 1998. New Modern: Architecture in the Age of Digital Technology. Assemblage 35, April.

Zizek, Slavoj. 1989. The Sublime Object of Ideology. London: Verso. 